\title{
A RIVERMEAD VISELKEDÉSES EMLÉKEZETI TESZT (RVMT) BEMUTATÁSA
}

\author{
KÓNYA ANIKÓ, CZIGLER BALÁZS
}

ELTE Pszichológiai Intézet, Budapest

E-mail: konya@izabell.elte.hu; czigler@ izabell.elte.hu

\section{RACSMÁNY MIHÁLY}

Szegedi Tudományegyetem, Pszichológiai Tanszék, Szeged

Department of Experimental Psychology, Bristol

E-mail: racsmany@edpsy.u-szeged.hu

\section{TAKÓ EMŐKE, TARISKA PÉTER}

Országos Pszichiátriai és Neurológiai Intézet, Memória Klinika, Budapest

\begin{abstract}
A Wilson, Cockburn és Baddeley által kifejlesztett RVMT azokat az emlékezeti képességeket vizsgálja, amelyekre a mindennapi életben szükségünk van, amelyek emlékezeti problémaként vagy amnéziás tünetként jelentkezhetnek. A személyek nevére, arcára, illetve a mindennapi tárgyakra való emlékezés, a prospektív emlékezet (emlékezés arra, amit majd tenni kell), a rövid publikus történetekre való emlékezés, a téri tájékozódás meghatározott feladathoz kötve, valamint a jelenben való tájékozódás képessége szerepel a próbák közt. A teszt különösen érzékeny a korfüggö feledékenység és a kóros amnézia elválasztására. A forgalomban lévő magyar felnött változat a szerzők munkája, amelynek kezdeti klinikai tapasztalatairól beszámolunk. Általános tapasztalat, hogy az amnéziás panaszok jelentös része és az ennek alapján készült amnéziás diagnózis nem esik a kóros tartományba, ugyanakkor az esettanulmányok rámutathatnak egy-egy képesség kiemelkedö gyengeségére. Tájékozódó vizsgálatok egészítik ki beszámolónkat a teszt gyermek változatának használatával kapcsolatban. Adataink lehetöséget kínálnak elméleti kérdések felvetésére: példaként a prospektív és retrospektív emlékek próbáit vetjük egybe neurológiai betegek tesztadatain és helyezzük a kérdést elméleti keretbe.
\end{abstract}

Kulcsszavak: $\quad$ amnézia, mindennapi felejtés, emlékezeti teszt, prospektív emlékezet 
Az emlékezeti zavarok feltárására tervezett tesztekkel kapcsolatban gyakran merül fel az a vád, hogy túlzottan laboratórium ízủek, kevéssé illeszkednek a betegek valós problémáihoz, idegenszerűségük következtében pedig frusztrálják az emlékezeti problémáik miatt amúgy is frusztrációt megélt betegeket. A nyolcvanas években a laboratóriumi emlékezetvizsgáló eljárások kritikájára adott válaszként született meg a Rivermead Viselkedéses memóriateszt (RVMT), amelynek legnagyobb erénye éppen az, hogy életszerű feladatokkal teszteli az emlékezet múködését. Az RVMT szervesen illeszkedik az emlékezetpszichológia ökológiai mozgalmába, amelynek legfőbb célja, hogy az emlékezet kutatói a laboratórium falait elhagyva, hétköznapi működés közben vizsgálják az emberi emlékezetet. A Rivermead Viselkedéses memóriateszt lényegesen finomabb elemzést tesz lehetővé, mint a korábbi eljárások, és ami nem elhanyagolható, használata a vizsgálati személy számára sem jelent különösebben megterhelő feladatot. Talán ennek köszönhető, hogy mindmáig az egyik legnépszerủbb emlékezeti vizsgálóeljárásnak számít, eddig több mint 15 nyelvre fordították le, többek között magyarra is. Az RVMT további előnyének számít, hogy létezik egy külön változata 5-10 éves gyerekek számára, valamint egy normarendszere 11-14 éves gyerekeknek, ami fejlődési emlékezeti rendellenességek vizsgálatát is lehetővé teszi (COCKBURN, SMITH, 1989; Wilson, Cockburn, BAdDeley, 1985; Wilson, IVANi-Chakian, Aldrich, 1991). Ezenkívül az RVMT-nek külön normarendszere van a 70 év feletti személyek részére, és létezik egy nehezített Rivermead Kibővített emlékezeti teszt (DEWALL, WILSON, BADDELEY, 1994) is, ami lehetővé teszi a korfüggő feledékenység, valamint az enyhébb emlékezeti zavarok feltárását és összevetését más súlyosabb esetek mintázatával.

\section{A VISELKEDÉSES EMLÉKEZETI TESZT ISMERTETÉSE}

A Rivermead Viselkedéses memóriatesztet (RVMT) Barbara Wilson, Janet Cockburn és Alan Baddeley fejlesztette ki és adta közre 1985-ben ${ }^{1}$ (lásd még DEWALL, WILSON, BADDELEY, 1994). A magyar változat - lévén alapvetően nem verbális teszt - csak a történetekre való emlékezésnél igényelt adaptációt. Egyéb vonatkozásban a teszt értékelését átvettük az angliai tesztvizsgálatokból (RACSMÁNY, KÓNYA, 1998). A vizsgálat alapvetően felnőttek vizsgálatára készült, a fiataloknak és gyerekeknek készült változatról később teszünk említést.

A teszt tizenegy feladatot tartalmaz, amelyet a vizsgálati személy számára megfogalmazunk. Az 1-2. kettős feladatban fényképet mutatunk, és arra kérjük a vizsgált személyt, hogy jegyezze meg az azon látható személy vezeték-és keresztnevét (lásd 1. ábra).

\footnotetext{
1 The Rivermead Memory Test (magyarul Rivermead Viselkedéses memóriateszt) három füzetből áll: Kézikönyv, Tesztvizsgálatok és Időskori emlékezetvizsgálatok. Ehhez tartozik még egy értékelőlap 11-14 éves gyerekek RVMT vizsgálatához. A teszt magyar nyelvű változatának terjesztője a Thames Valley Test Company.
} 

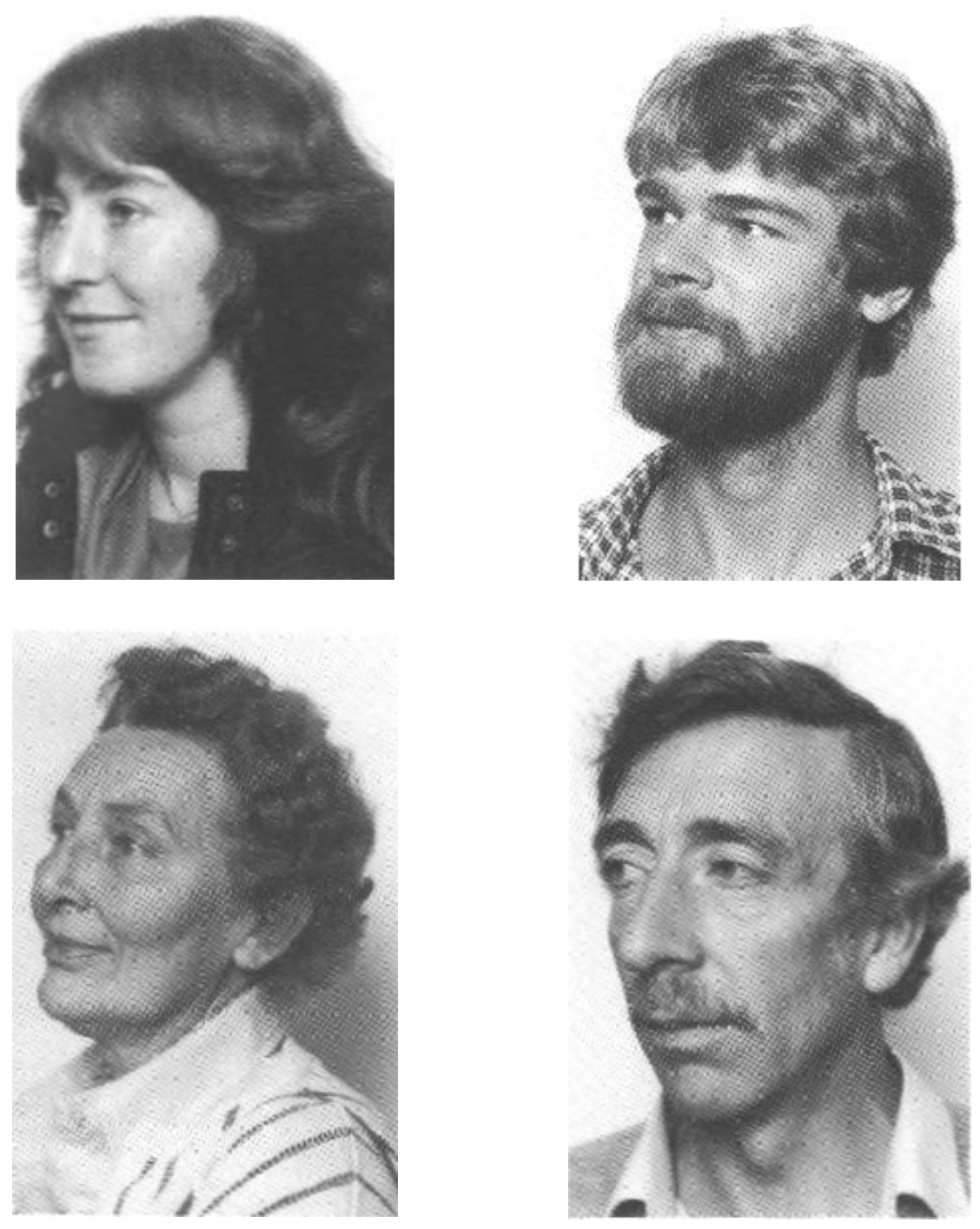

1. ábra. Vezeték- és keresztnévtanulás

A 3. használati tárgy feladatban arra kérjük a vizsgálati személyt, hogy adja át nekünk valamely nála lévő használati tárgyát, és a vizsgálat végén majd kérje azt vissza, illetve mondja meg, hol van elrejtve. A 4. megbeszélt időpont feladat esetében az órát 20 perccel későbbi csöngetésre állítjuk, és arra kérjük, hogy a megbeszélt kérdést tegye fel, amikor megszólal az óra. Az 5. képek feladatban a vizsgálati személy tíz tárgyat ábrázoló képet lát, feladata lesz ezeket később felismerni más képek közé keverve (lásd 2. ábra). 

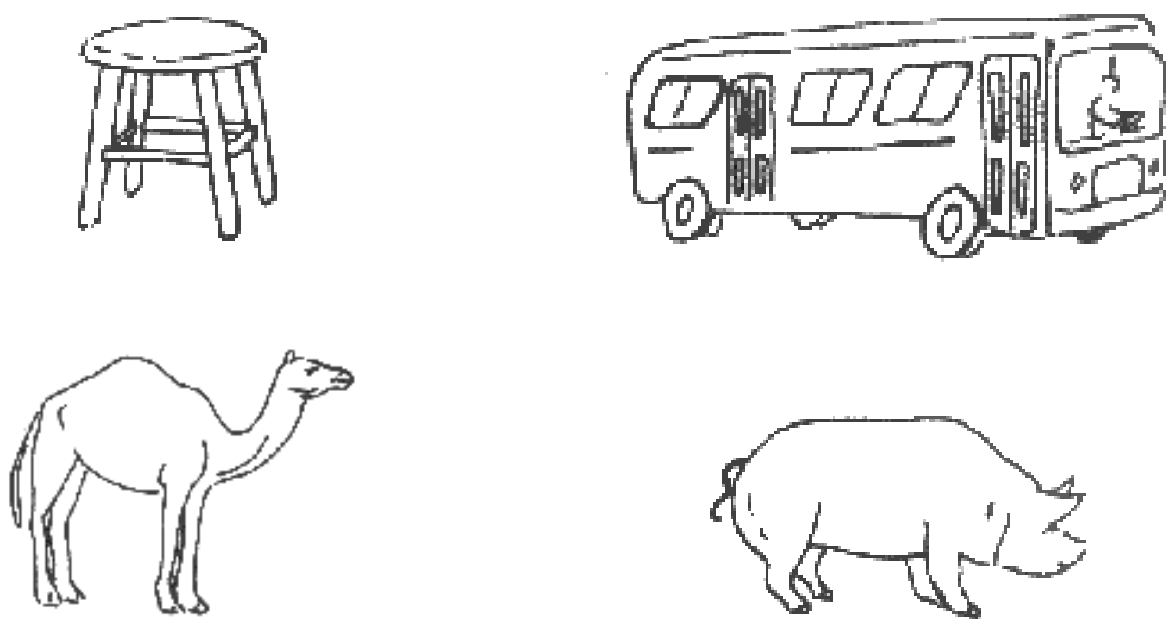

2. ábra. Képek felismerése

A 6. történet feladatban rövid történetet hall a vizsgálati személy, ezt kell felidéznie azonnal, illetve késleltetve. A 7. arcok feladatban - hasonlóan, mint a képeknél - öt arcot kell felismerni más, nem látott képek között. A 8. feladat az útvonal: a szobában rövid, öt állomásból álló útvonalat mutatunk be, amit azonnali ismétléssel, majd késleltetett felidézéssel is rekonstruálnia kell (lásd 3. ábra). A 9. üzenet: az előbbi feladat során egy borítékot is magunkkal viszünk, és egyik helyen letesszük. A feladat ugyanennek az elvégzése az útvonalfeladat során.

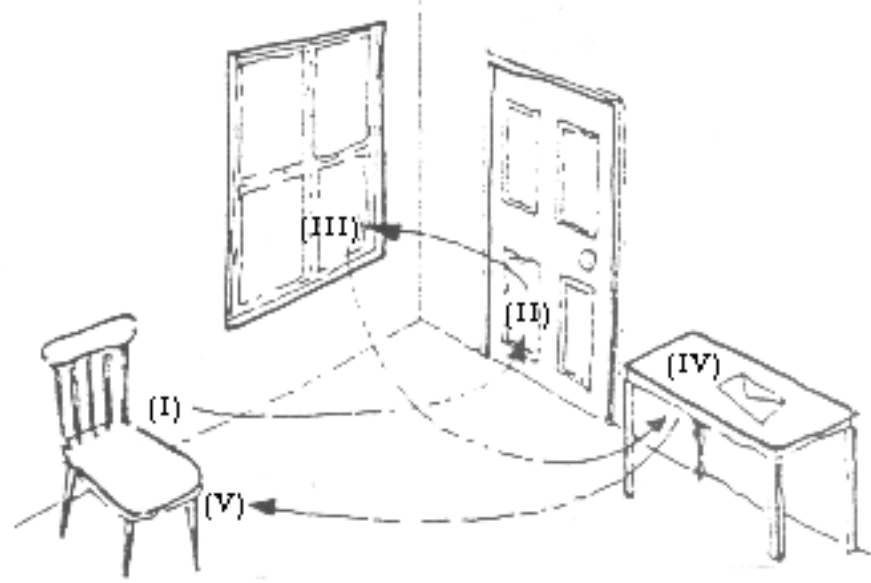

3. ábra. Útvonaltanulás

(I) Szék (II) Ajtó (III) Ablak (IV) Asztal (V) Vissza a székhez 
A 10. és 11. orientáció és dátum feladatban kérdéseket intézünk a vizsgálati személyekhez a téri, idői és általános tájékozottságot illetően.

Az RVMT-nek két pontozási rendszere van, a sztenderd profil pontszám és a szűrő pontszám, amelyek alapján eldönthető az esetleges emlékezeti károsodás szintje. A tesztben kapott konkrét, ún. nyers pontszámokat a táblázat alapján sztenderd pontszámmá kell alakítani, hogy az altesztekben lévő különbségek kiegyenlítődjenek; minden feladatra egységesen maximum két pont adható. A sztenderd profil pontszámokhoz képest a szűrő pontszámok már csak 0 vagy 1 értéket vehetnek fel, így már csak azt mutatják, hogy a vizsgált személy az adott feladatot teljesítette-e vagy sem. A Sztenderd profil pontszám érzékenyebb besorolást eredményez, jobban széthúzza a pontsávot, ezért összehasonlító vizsgálatoknál ezzel számolhatunk, míg a Szürőpont ehhez képest durvább, kifejezetten a klinikai szűrést szolgálja. Az emlékezeti szintek a következőképp alakulnak: súlyosan károsodott emlékezet, enyhén károsodott emlékezet, gyenge emlékezet, normális emlékezet. A tesztnek négy változata van, így elkerülhető, hogy az ismételt vizsgálatokat ugyanazzal a tesztanyaggal kelljen elvégezni. A teszt felvétele egyénileg történik, amely hozzávetőleg fél-fél órát vesz igénybe.

\section{HAZAI TAPASZTALATOK}

A tanulmányban tárgyalt vizsgálatok a teszt bemutatását szolgálják. Az eredmények a megnevezett mintákra érvényesek. Általuk szemléltetjük a klinikai vizsgálatok és az emlékezet általánosabb vizsgálatának lehetőségét.

Tanulmányunkban a neurológiai csoport szolgál kiindulásként, amelynek kialakítását Márkus Attila tette lehetôvé a budapesti MÁV kórház neurológiai rendelőjében. ${ }^{2} \mathrm{~A}$ betegek vegyes diagnózisú amnéziás betegek, 52 személy vett részt a vizsgálatban. A 4. ábra a magyar és angol klinikai adatok RVMT-profilját rajzolja ki. Az ábrázolások a sztenderd pontszám (max. 24) alapján történtek. Hazai mintánk kis elemszámú. A teszt magyar és angol klinikai profilját a részpróbák által összehasonlítva ez ki is tủnik. Szemmel láthatóan egyenetlenebb a magyar profil, amely első megközelítésben a kis minta esetleges voltával magyarázható.

A profil a vizsgált minták közt is változik. Ezt szemléltetjük a klinikai csoportnak a korfüggő csoporttal történő összehasonlítása által az 5.ábrán. Mindenekelőtt a klinikai csoporthoz hasonlóan a korfüggő csoportnál is láthatjuk, hogy a próbák ereje a sztenderd pontszámok használata ellenére nem egyforma. A két csoport különbségeinek értelmezése kiterjedtebb vizsgálatot igényel.

A klinikai csoport továbbra is a MÁV kórház vizsgálati anyagát jelenti. Az ún. korfüggő csoport vizsgálatára ugyancsak Budapesten, az Országos Pszichiátriai és Neurológiai Intézet Memória Klinikáján került sor Tariska Péter és Takó Emőke irányításával. ${ }^{3}$ A korfüggő feledékenységre irányuló vizsgálatba olyan betegek kerültek

2 A vizsgálatokat Deli Károly végezte el.

3 A vizsgálatokat Nagy Lívia és Tóth Krisztina végezte el. 


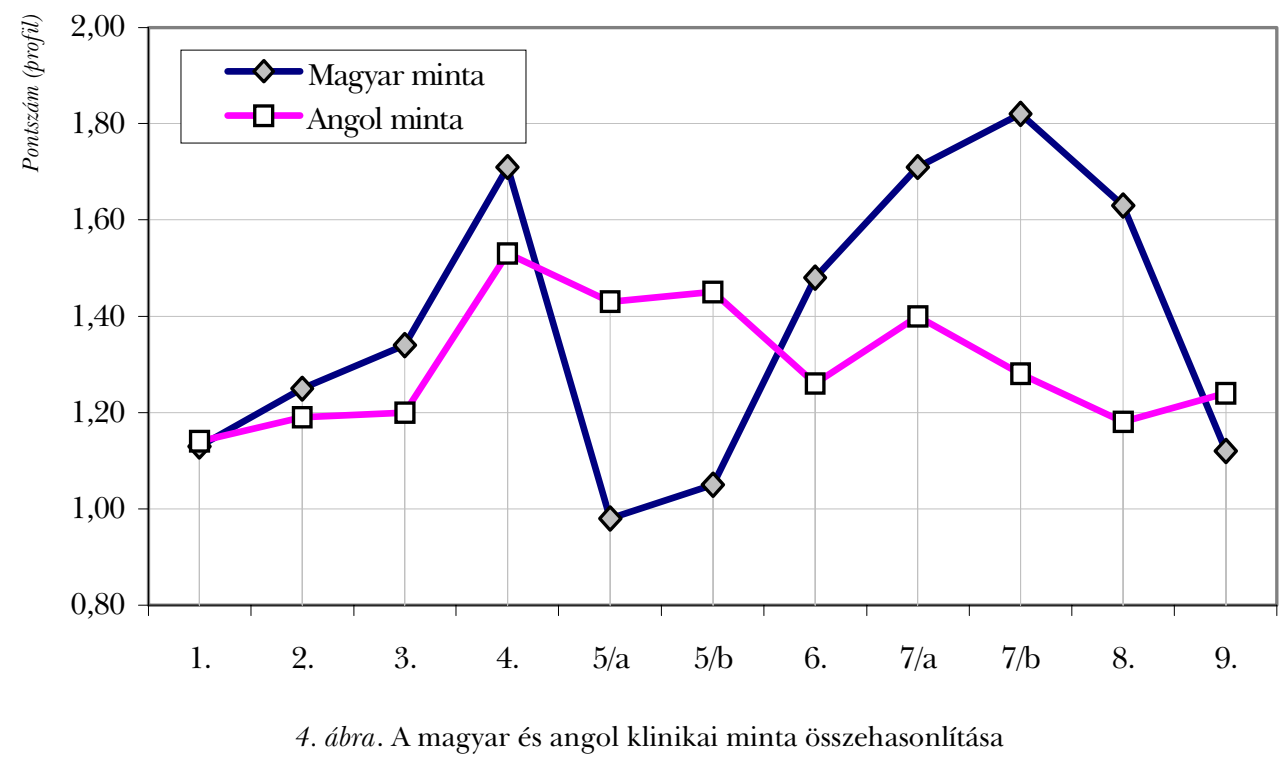

1. Nevek; 2. Tárgy; 3. Időpont; 4. Képek; 5/a Történet azonnal; 5/b Történet később; 6. Arcok; 7/a Útvonal azonnal; 7/b Útvonal később; 8. Üzenet; 9. Orientáció/Dátum

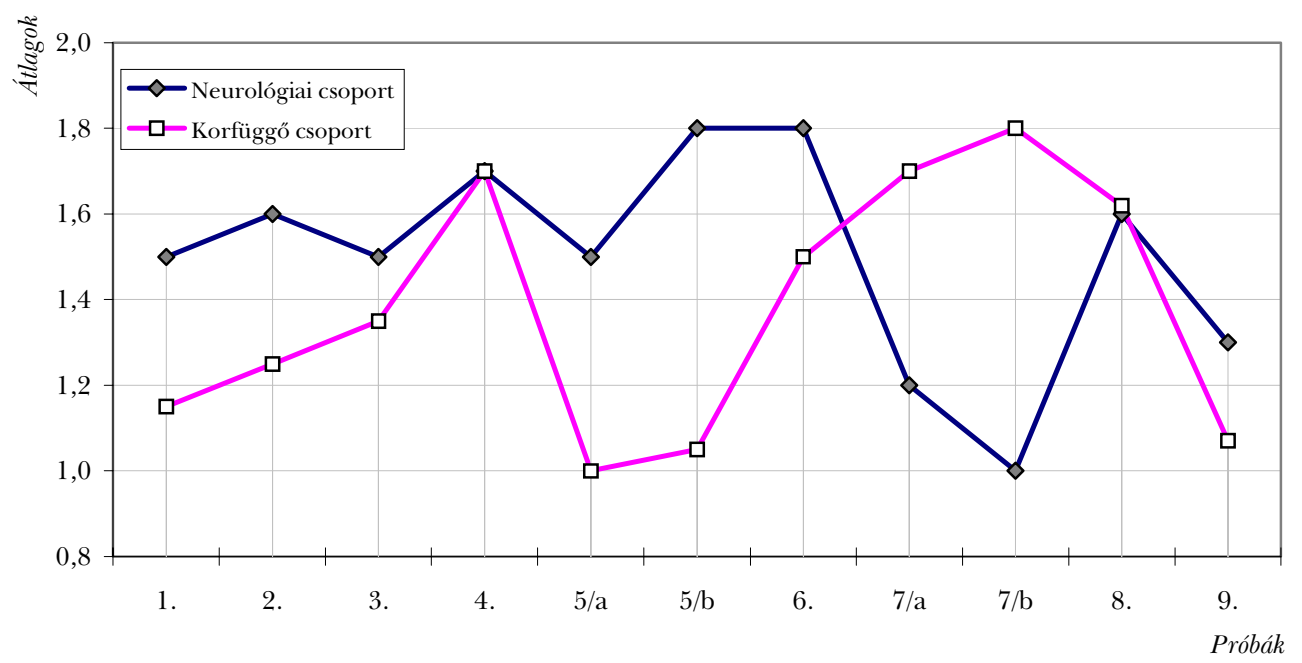

5. ábra. Kétszeres interakció

$\mathrm{F}(10,600)=4,47 ; \mathrm{p}<0,00001$

1. Nevek; 2. Tárgy; 3. Időpont; 4. Képek; 5/a Történet azonnal; 5/b Történet később; 6. Arcok; 7/a Útvonal azonnal; 7/b Útvonal később; 8. Üzenet; 9. Orientáció/Dátum 
(10 személy), akiknél nem ismerhető fel kóros agyi folyamat, amely az emlékezés zavarát magyarázná. Náluk a kórisme a mindennapi élethelyzetekben mutatkozó zavar, amely okán a Rivermead Viselkedéses memóriateszt kipróbálása kifejezetten indokolt - annál is inkább, mert az életkornak megfelelő fiziológiás, valamint a kóros amnézia között nem éles a határ (MIHOCSA, TARISKA, 1996).

A továbbiakban a neurológiai csoport anyaga alapján szemléltetjük a betegek emlékezeti szintjeinek eloszlását, amelyet a sztenderd pontszámok határolnak be (lásd 6. ábra).

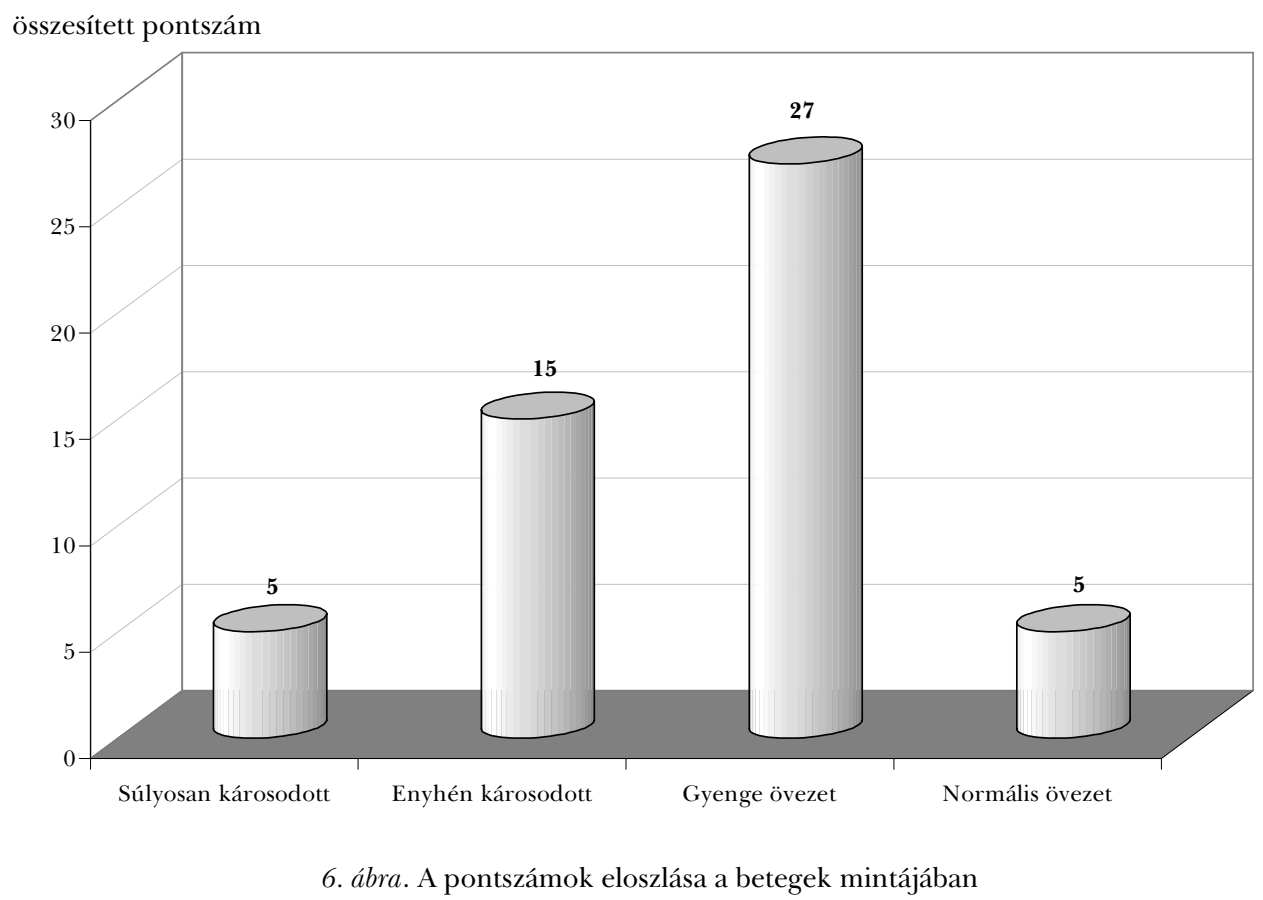

Figyelemre méltó - és a teszt klinikai pszichológiai erejét bizonyítja -, hogy az amnéziásnak mondott betegeknek hozzávetőleg a fele mondható csak kóros állapotúnak. Panaszukra a teszt összpontszáma alapján történő besorolás nem ad magyarázatot. Ezen a szálon továbbmenve, a próbák közötti különbségekben kerestük a magyarázatot, amit nem találtunk meg.

A statisztikai elemzések megerősítették a próbák eltéréseit, ugyanakkor nem lehetett ily módon, csoportosan bizonyítani az emlékezet szelektív sérülését. A vegyes diagnosztikai kategóriákba eső amnéziás betegekről általában nem állítható, hogy például a képekre és arcokra való emlékezés disszociálódna egymástól, vagy hogy akár a történetfelidézés leválna a többi képességtől.

A fentiek okán annak a kérdésnek a megválaszolásához, hogy mi is okozhatja az emlékezeti panaszt a nem kórosan amnéziás személyeknél - akik a többséget 
képezik (!) -, az egyéni tesztprofilokra tértünk át. A 7. majd 8. ábrán ábrázolt egyéni tesztmintázatról leolvashatjuk, hogy $H$. A betegnek a történet azonnali felidézésével van a legnagyobb gondja. A késleltetett felidézés átlagos teljesítményéhez képest az azonnali felidézésben jobban megmaradnak a részletek és segíthet a szószerintiség. Sz. I. pedig az általános orientáltság mellett a prospektív emlékezet zavarát mutatja. A jövőbeli teljesítmény kivitelezéséhez a viselkedés tudati monitorozása szükséges ahhoz, hogy az adott pillanatban a viselkedést félbeszakítsuk. H. A. emlékezete az emlékezeti szintek besorolása szerint normális, $S z$. I. emlékezete pedig csak gyenge. Panaszukat sajátos emlékezeti zavarok és nem általános emlékezeti károsodás okozzák. Mindez terápiás szempont lehet az egészséges és kóros emlékezeti készségek tudatosításában, és az utóbbiak kompenzálásában.

Az esetelemzések tanulságai megerősítik az RVMT egyéni mintázatának fontosságát. Az egyéni jegyzőkönyvek próbánként jelzik a kiugróan jó/rossz/gyenge teljesítményt a sztenderd profil és a szűrő pontokat egyidejủleg figyelve. Az amnéziás panasz a rossz, illetve gyenge próbák helyzeteiből fakadhat, miközben több próbában jól teljesít a személy.

\section{A RIVERMEAD VISELKEDÉSES MEMÓRIATESZT FIATALKORI VÁLTOZATA EGY DISZLEXIÁS VIZSGÁLATON SZEMLÉLTETVE}

A memóriateszt fiatalok számára készített változatát, amely 11-14 éves gyerekek sztenderdjén alapul, Bende Katalin próbálta ki diszlexiás fiatalokkal végzett vizsgálatában. A diákok diszlexiásokat is oktató szakközépiskolában tanultak (tizenegy 14-16 éves személy). E vizsgálat annak kizárását célozta, hogy van-e a diszlexiások adott csoportjának emlékezeti problémája, és ha van, az miből fakad. A vizsgálat előtt elmondtuk a gyerekeknek, hogy emlékezettel kapcsolatos teszt felvételéhez kérjük a segítségüket, majd a teszt elvégzése után válaszoltunk az esetleges kérdéseikre és megköszöntük részvételüket. Mindössze a közéleti témájú orientációs kérdésekben mutattak a gyerekek némi tájékozatlanságot, ami a korosztályra jellemző. A vizsgálat ennél a jól iskolázott diszlexiás csoportnál kizárta a háttérben álló emlékezeti problémát. Az indirekt módon feltett kérdés - van-e emlékezeti zavar a diszlexia mögött - azonban nyitott marad, további vizsgálatokat igényel. A további, a diszlexia kérdésfeltevését is érintő vizsgálatokat szolgálhatja az 5-10 éves gyermekeknek készült Rivermead-változat, amelyhez hazai tapasztalatokat még nem tudunk sorakoztatni (WILSON, IVANI-CHAKIAN, ALDRICH, 1991), valamint más, elsősorban a rövid távú emlékezet működését vizsgáló eljárások alkalmazására sem. 


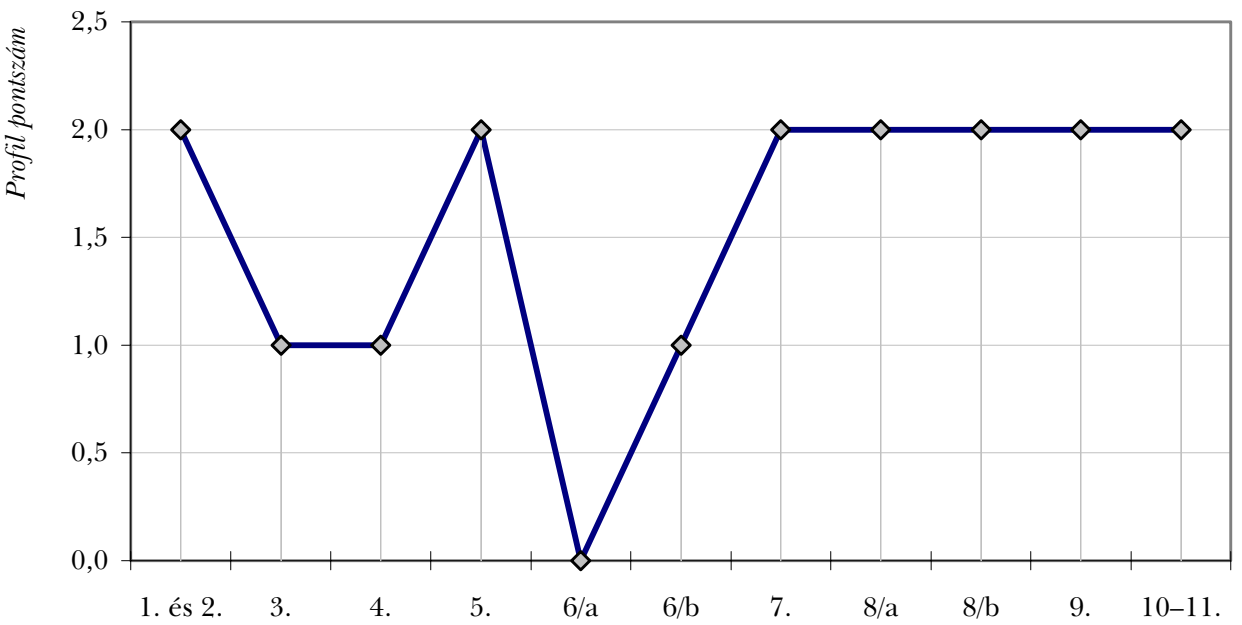

7. ábra. H. A. emlékezeti teljesítménye

1. és 2. Vezeték- és keresztnév; 3. Használati tárgy; 4. Megbeszélt időpont; 5. Képek; 6/a Történet- (azonnali) felidézés; 6/b Történet- (késleltetett) felidézés; 7 . Arcok;

8/a Útvonal- (azonnali) felidézés; 8/b Útvonal- (késleltetett) felidézés;

9. Üzenet boríték azonnali és késleltetett felidézése; 10-11. Orientáció és dátum

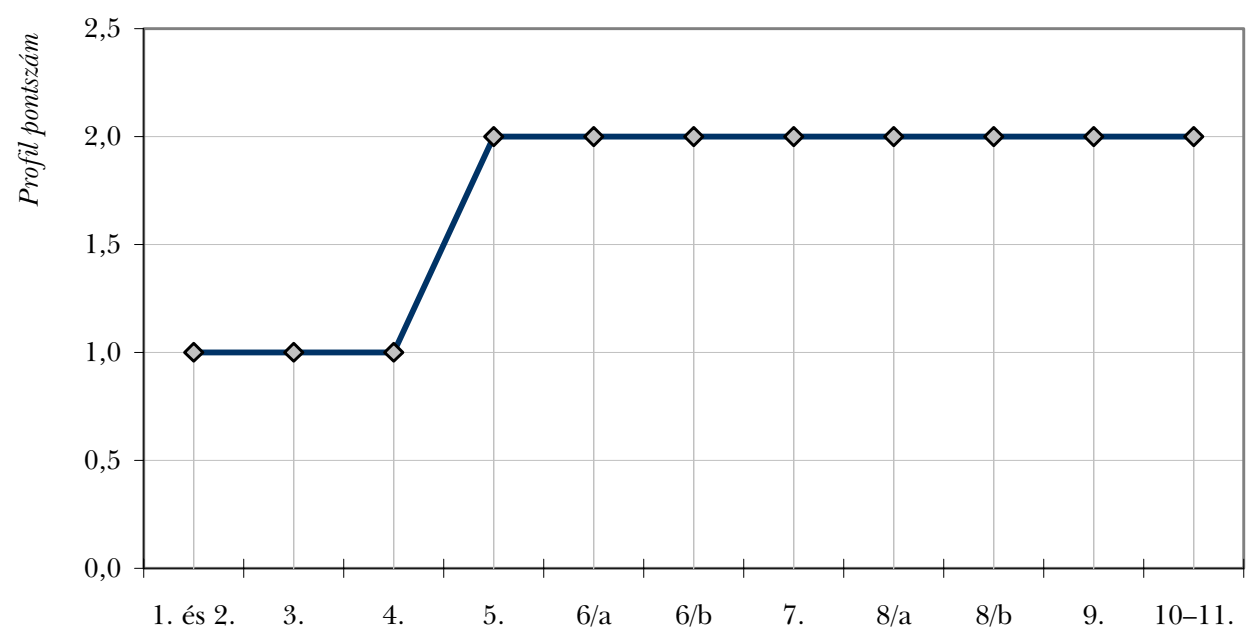

8. ábra. Sz. I. emlékezeti teljesítménye

1. és 2. Vezeték- és keresztnév; 3. Használati tárgy; 4. Megbeszélt időpont; 5 . Képek; 6/a Történet- (azonnali) felidézés; 6/b Történet- (késleltetett) felidézés; 7. Arcok;

8/a Útvonal- (azonnali) felidézés; 8/b Útvonal- (késleltetett) felidézés;

9. Üzenet boríték azonnali és késleltetett felidézése; 10-11. Orientáció és dátum 


\section{EGY ELMÉLETI KÉRDÉS: \\ A PROSPEKTÍV EMLÉKEZET VIZSGÁLATA ${ }^{4}$}

Neurológiai és korfüggő csoportjaink adatait használtuk fel arra, hogy - statisztikai utóelemzés keretében - megvizsgáljuk, milyen kapcsolat van az RVMT prospektív és retrospektív emlékezeti teljesítményt mérő részpróbái között.

A prospektív emlékezet a jövőben végrehajtandó cselekvésekre, jövőbeli eseményekre való emlékezés. Mikor „majd” végre akarunk hajtani egy cselekvést, emlékeznünk kell egyrészt arra, hogy meg kell tennünk valamit; másrészt viszont emlékeznünk kell arra, hogyan is hajtandó végre az adott tevékenység, ami retrospektív tevékenységet igényel. Már ezen a ponton látható, hogy a reális cselekvéseket tekintve nehezen választható el az emlékezet e két típusa. Vannak olyan nézetek is, melyek szerint a prospektív memória maga sem egységes rendszer. Talán másképpen emlékszünk azokra a cselekvésekre, amelyeket magunk határozunk el, és máshogy azokra, amelyeket mások jelölnek ki számunkra. EINSTEIN és MCDANiEl (1990), majd BuRGESS és SHALlicE (1997) annak alapján különböztet meg kétféle prospektív memóriát, hogy mi az adott cselekvés kiváltója. Az egyik típus az időn alapuló, ilyen esetekben adott időpontban vagy bizonyos idő elteltével kell megtenni valamit. A másik típus az eseményen alapuló: valamely esemény megtörténtekor kell végrehajtani valamely cselekvést (pl. kivenni az ételt a sütőből, ha az csenget). Az előbbire nehezebb emlékezni, mert ekkor figyelni kell az idő múlását, és magunkra vagyunk utalva a feladat fejben tartásában is. Esemény alapú emlékezés esetében külső támpontok segíthetnek a teendők felidézésében. $\mathrm{Az}$ alábbi kísérlet hasonlítja össze a kétféle helyzetet. Ebben a személyeknek egy gombot kellett megnyomniuk vagy megadott időpontokban, vagy bizonyos helyeken. Az első, idő alapú helyzetben jelentősen rosszabb volt a válaszarány, mint az utóbbi, inkább esemény alapúnak számító feladatban. Ezt a jelenséget a mindennapokban igyekszünk is kihasználni, ha tehetjük, esemény alapúvá alakítjuk az idő alapú megjegyeznivalókat: csomót kötünk a zsebkendőnkre, hogy az felidézési támpontként szolgáljon. Persze vannak kifinomultabb módszerek is ugyanerre. Idős személyek hajlamosabbak ilyen támpontok használatára (környezetük, orvosaik is javasolják számukra ezeket a módszereket), így egyes vizsgálatokban azt találták, hogy ők jobban teljesítenek prospektív feladatokban. Más vizsgálatok ennek ellenkezőjét találták (lásd alább).

Mint a pszichés folyamatokat általában, a prospektív emlékezeti teljesítményt is befolyásolják motivációs tényezők. A fontos eseményekről általában kevésbé feledkezünk meg. Egy kísérletben a személyek nyolc képeslapot kaptak, hogy feladják azokat postán, heti egyet. Egy másikban a személyeknek bizonyos időpontokban fel kellett hívniuk telefonszámot. Mindkét esetben volt egy pénzzel jutalmazott és egy jutalmazást nem kapó csoport; mindkét esetben pontosabban teljesítettek a jutalmazott személyek. A prospektív emlékezet eddigi említett tényezői természetesen nem függetlenek egymástól: valamely cselekvés végrehajtására erősen moti-

${ }^{4}$ Czigler Balázs (kézirat, 1999) 
vált személyek hajlamosabbak lehetnek arra, hogy külső emlékeztetőket használjanak a biztosabb felidézés érdekében.

Érdemes áttekinteni, hogy az általunk alkalmazott viselkedéses emlékezetvizsgáló eljáráson kívül milyen egyéb módszerekkel tanulmányozható a prospektív emlékezet. Az adatgyüjtés talán legegyszerủbb módját a kérdőíves módszerek jelentik, amikor is megkérdezik a személyeket, hogy milyen gyakran fordul elő vele az, hogy elfelejt találkozókat, időpontokat. Ezzel a módszerrel az a nyilvánvaló probléma, hogy az emberek néha olyannyira elfelejtik ezeket, hogy arról sem tudnak beszámolni, hogy „meg kellett volna tenniük valamit, de elfelejtették”. A kísérletes módszerek ebből a szempontból kedvezőbbek lehetnek. Ezek során arra kérik a személyt, hogy hajtson végre bizonyos cselekvéseket, például adjon fel egy levelet, telefonáljon, nyomjon meg egy gombot meghatározott időpontokban vagy helyzetekben, akár a fent idézett vizsgálatok során. Ilyenkor kísérleti kontroll alá vonhatóak olyan tényezők, mint a felidézésig eltelő idő, motiváció vagy a feladat minősége, komplexitása. Ugyanakkor csorbát szenvedhet a helyzet ökológiai validitása például abban a tekintetben, hogy az emberek normális körülmények között hajlamosak külső emlékezeti támpontokhoz fordulni. Az RVMT prospektív részpróbái a kísérletes módszer példái, a feladatok azonban nem idegenek a valós életben is előfordulóktól. A vizsgált személy alkalmazhat emlékeztetőket is, ha akar.

Lássuk most röviden, milyen további elméletek születtek a prospektív emlékezet természetéről! KORIAT, BEN-YUR és NUSSBAUM (1990) azt találták, hogy azok a személyek, akiknek egy sor feladatra kellett emlékezniük, jobb teljesítményt nyújtottak abban az esetben, ha feladatot motorosan kellett felidézni - vagyis végre is kellett hajtani -, mint ha verbálisan tesztelték őket. Ebből a szerzők azt a következtetést vonták le, hogy a prospektív emlékezet, legalábbis részben, enaktív, motoros reprezentációt használ. Ha a reprezentáció verbális lenne, valószínűleg hatékonyabbnak bizonyulna a verbális előhívás. Fenti szerzők szerint „egy jövőbeni esemény kódolása magában foglalja a feladat szimbolikus lejátszását...”. Ez megfelel az olyan elképzeléseknek, amely szerint egy cselekvés vagy cselekvéssor többszörösen reprezentált és ezen reprezentációk szerveződése hierarchikus. A hierarchia csúcsán a cselekvés általános célja található, az alsóbb szinteken pedig specifikus részletek reprezentálódnak. A mosogatás közkedvelt példáján szemléltetve, általános cél lehet a piszkos edények tisztává varázsolása, specifikusabb a vízcsap ehhez szükséges kinyitása, még specifikusabb a kéz ujjainak megfelelő mozgatása. Az, hogy milyen szintű reprezentáció irányítja a viselkedést, függ attól, hogy a cselekvés kivitelezése milyen szakaszban van, mennyire nehéz, idegen vagy komplex a feladat. Egyszerü, ismerős, begyakorolt feladatok esetében a kontroll elsődlegesen a magasabb szintű reprezentációé.

Elemzésünkben elsősorban a prospektív és retrospektív emlékezet viszonyára vagyunk kíváncsiak. Eredményeink ismertetése előtt áttekintünk néhány kísérleti tapasztalatot és elméleti megfontolást e szukkebb témakörben. A fejezet elején felmerült már az, hogy a korábban eltervezett cselekvés végrehajtása érdekében nem csak arra kell emlékeznünk (prospektíven), hogy azt végre kell hajtani, hanem 
(retrospektíven) arra is, hogy milyen módon hajtandó végre a cselekvés. Az öszszefonódás itt nyilvánvaló. Sok szempontból elválik azonban a két emlékezet típusa. A prospektív emlék anyagát általában a személy maga generálja. A mások által kijelölt teendők esetében is meg kell terveznünk ezek végrehajtását, be kell azt illesztenünk terveinkbe. Valójában ez a prospektív emlékezés legalapvetőbb, legérdekesebb jellemzője, az tehát, hogy mindig magában foglal akarati, tervezéses komponenseket. Több kísérlet vizsgálta azt, hogy milyen mértékủ korreláció van a prospektív és retrospektív emlékezeti feladatokban nyújtott teljesítmény között. Nem találtak vagy egyenesen negatív korrelációt találtak a prospektív és retrospektív feladatok között, a prospektív kárára. Ezen eredmények áttekintését adja Burges és Shallice (1997). Korábban például Wilkins és BADDELey (1978) egyszerre megjegyzendő prospektív és retrospektív feladatok között talált ilyen kapcsolatot: ebben a feladatban a személyeknek meg kellett nyomniuk egy gombot bizonyos időpontokban, a második feladat pedig szavak szabad felidézése volt. KVAVILASHVILI (1987) pedig egyazon feladaton belül talált negatív együttjárást aközött, hogy a személyek mennyire emlékeztek arra, hogy át kell adniuk egy üzenetet a kísérletvezetőnek, és hogy mennyire voltak képesek felidézni ennek az üzenetnek a tartalmát. Ezt a hatást - vagyis azt, hogy a jó verbális emlékezetủ személyek elfelejtették az időpontokat - szórakozott professzor hatásnak nevezték el. COCKBuRn és SMITH (1989) ezzel szemben azt találta - éppen az általunk is használt RVMT-vel végzett vizsgálatokban -, hogy a prospektív emlékezet az életkorral a retrospektívnél jelentősebben romlik, ami a két rendszer különbségére utal. Itt kapcsolódunk saját vizsgálatainkkal.

Az RVMT két prospektív részpróbája közül a használati tárgy feladat inkább idő alapú (a beszélgetés végeztével a személynek vissza kell kérnie egy tárgyat, amelyet a vizsgálat elején kért el tőle a vizsgálatvezető). A megbeszélt időpont részpróba viszont esemény alapúnak tekinthető (egy ébresztőóra csöngése jelzi a vizsgálati személynek, hogy tegyen fel bizonyos, előre megbeszélt kérdéseket). Adataink tehát lehetővé tették a prospektív emlékezet e két típusának összevetését is. Korfüggő feledékeny mintánkon pedig vizsgálhattuk azt, hogy a személyek a prospektív feladatokban inkább vagy kevésbé mutatnak hanyatló teljesítményt az életkor előrehaladtával.

Adataink elemzése során először összevetettük az idő, illetve eseményfüggő részpróbáink eredményeit, feltételezve, hogy az esemény alapú „megbeszélt időpont” próbában (ahol is ébresztőóra csöngése jelzi a vizsgálati személynek, hogy tegyen fel bizonyos, előre megbeszélt kérdéseket) a teljesítmény magasabb. Elemzésünk ezt nem erősítette meg (VA: $\mathrm{F}(1,51)=0,57 ; \mathrm{p}<0,45)$.

Ezt követően összesítettük a prospektív, illetve a retrospektív feladatok eredményeit. A két feladattípus kapcsolatát vizsgálandó korrelációkat számítottunk e két mutató között. Szignifikáns pozitív kapcsolat adódott, vagyis a két részpróba teljesítménye együtt jár $(\mathrm{r}=0,57 ; \mathrm{p}<0,001)$. A függetlenség további ellenőrzése végett khi-négyzet próbát is végeztünk, mely nem mutatott szignifikanciát $\left(\mathrm{khi}^{2}=63\right.$; $\mathrm{p}=0,23)$. A részpróbákat egyenként tekintve a két prospektív feladat több esetben 
magasabb együttjárást mutatott a retrospektív feladatokkal, mint a retrospektív feladatok egymás között. Mindezekből arra következtethetünk, hogy az emlékezet e két típusa nem választható szét, a két teljesítmény „közös tőről fakad”.

Annak eldöntésére, hogy a prospektív vagy a retrospektív feladatokban nyújtott teljesítmény romlik-e inkább a korral, támpontot nyújthatott korfüggő feledékeny mintánk adatainak elemzése. Egyszempontos ismételt méréses varianciaanalízist végeztünk a próbák átlagpontszámainak összehasonlítására, mely nem mutatott szignifikáns próbák közötti különbséget $(\mathrm{F}(10,90)=1,52 ; \mathrm{p}<0,1152)$. Megtekintve az átlagokról készült ábrát (lásd 9. ábra), szemmel látható, hogy a két prospektív feladatban nyújtott teljesítmény nem különül el az RVMT többi próbájában mutatott teljesítménytől.

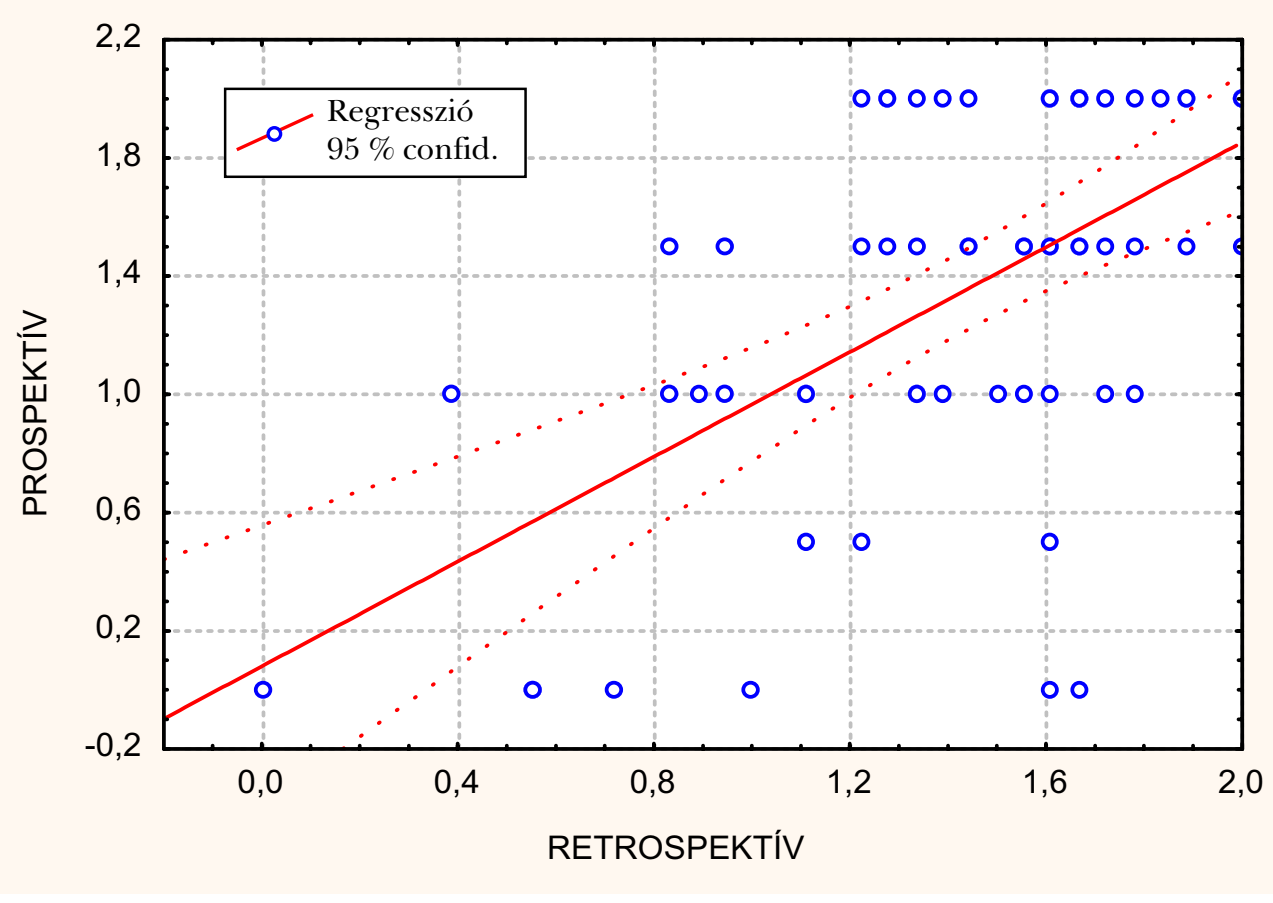

9. ábra. A retrospektív és prospektív feladatok korrelációja Korreláció: $\mathrm{r}=0,57967 ; \mathrm{p}<0,001$

Korfüggő csoportunktól nyert adatainkat megerősítették neurológiai betegeink korrelációs eredményei is, melyet a 10. ábra látványosan mutat. További lépésként kétszempontos varianciaanalízist számítottunk a prospektív és retrospektív részpróbák pontszámain csoport (korfüggő vs. neurológiai csoport) $\times$ feladat (prospektív vs. retrospektív) elrendezésben, melyek továbbra sem választották le a kétféle emlékezést egymásról (sem a fóhatások [csoport: $\mathrm{p}=0,31$; feladat: $\mathrm{p}=0,1$ ], sem az interakció $[p=0,13]$ nem mutatott szignifikanciát). 


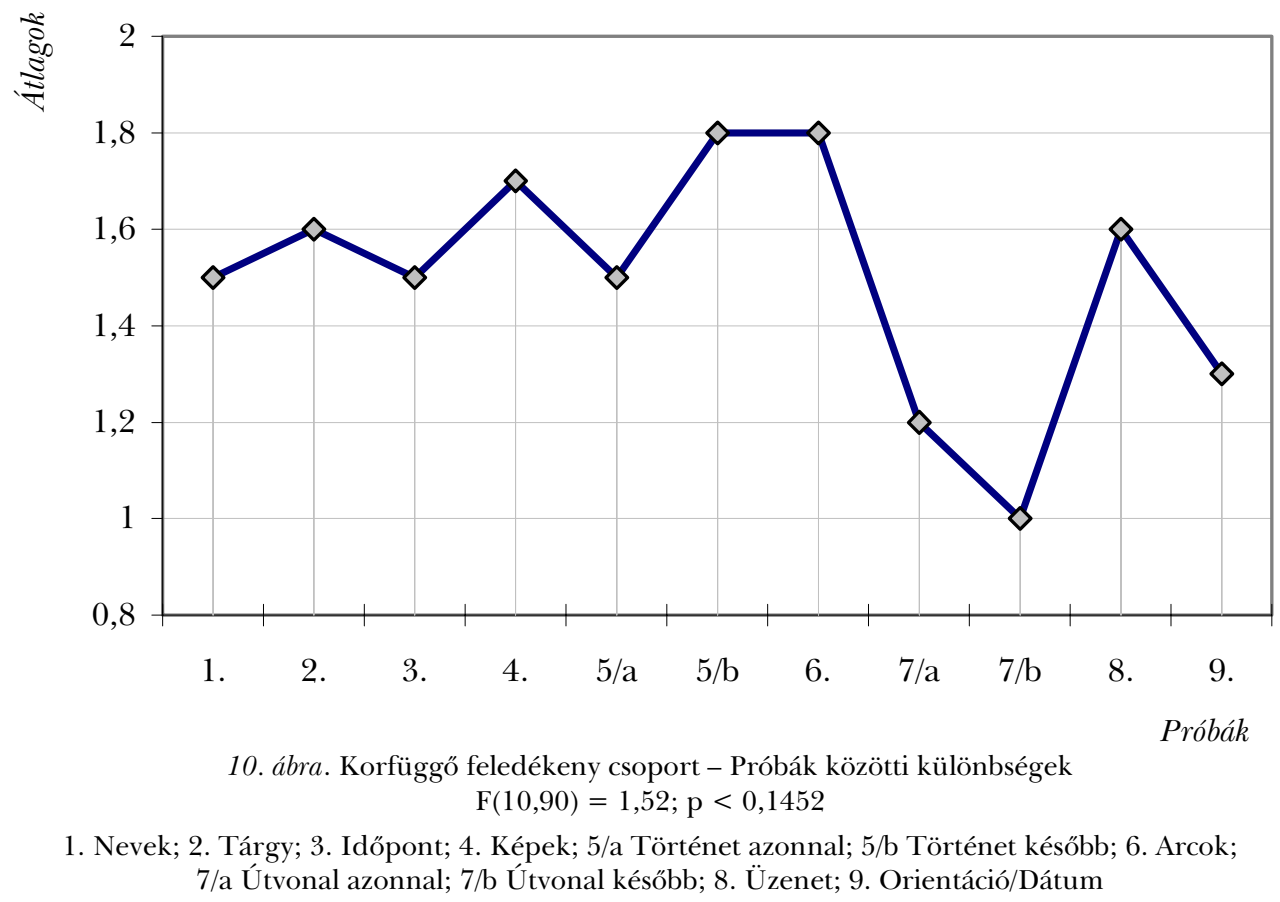

Összefoglalásképpen azt mondhatjuk, hogy elemzésünk nem támasztja alá azt az elképzelést, hogy a prospektív és retrospektív emlékezet egymástól elkülönülő képességek. Neurológiai csoportunk személyei között azonban találhatóak olyanok (lásd korábban $S z$. I. profilját), akiknél megtartott retrospektív emlékezet mellett alacsony teljesítményt mértünk a prospektív részpróbákban. Talán mégis elképzelhető disszociáció a két teljesítmény között? A kérdés megválaszolása további adatgyűjtést és az amnézia diagnosztizált formáinak elemzését kívánja.

\section{IRODALOM}

Burgess, P. W., Shallice, T. (1997) Relationship between prospective and retrospective memory: neuropsychological evidence. In Conway, M. A. (ed.) Cognitive models of memory. Psychological Press

Cockburn, J., Smith, P. T. (1989) The Rivermead Behavioural Memory Test. Supplement 3: Elderly People. Bury St. Edmunds, TVTC

DeWall, C., Wilson, B., Baddeley, A. (1994) The Extended Rivermead Behavioural Memory performance in normal adults. In Gathercole, S., McCarthy, R. (eds) Memory tests and techniques (Special issue of Memory). Lawrence Erlbaum Associates, Hove 
Einstein, G. O., MCDaniel, M. A. (1990) Retrieval processes in prospektive memory. Journal of Experimental Psychology: Learning, Memory and Cognition, 16, 717-726.

Koriat, A., Ben-Yur, H., Nussbaum, A. (1990) Encoding information for future action: Memory for to-be performed tasks versus memory for to be recalled tasks. Memory and Cognition, 18, 568-578.

KVAVILASHVILI, L. (1987) Remembering information as a distinct form of memory. British Journal of Psychology, 78, 507-518.

RaCSMÁny M., KónYa A. (1998, fordítás) Rivermead Viselkedéses memóriateszt. Thames Valley Test Company

Wilkins, A. J., BAdDEley, A. (1978) Remembering to recall in everyday life: an approach to absent-mindedness. In Gruneberg, M. M., Morris, P. E., Szkes R. N. (eds) Practical aspects of memory. 27-34. Academic Press, New York

Wilson, B., Cockburn, J., Baddeley, A. (1985) The Rivermead Behavioral Memory Test. Thames Valley Test Company

Wilson, B., IVAni-Chakian, R., Aldrich, F. (1991) The Rivermead behavioral memory test for children aged 5 to 10 years. Thames Valley Test Company

\title{
INTRODUCTION \\ OF THE RIVERMEAD BEHAVIOURAL MEMORY TEST (RBMT)
}

\author{
KÓNYA, ANIKÓ-RACSMÁNY, MIHÁLY-CZIGLER, BALÁZS-TAKÓ, EMŐKE-TARISKA, PÉTER
}

The Rivermead Behavioural Memory Test (RBMT) has been developed to unfold everyday memory problems. This test involves a series of tasks concerning face recognition and name recall. To acquire a high score on the test patients need to recall short stories, routes and remember things to do in the future (prospective tasks). A general problem in diagnosing amnesia is that a large proportion of everyday memory problems is outside the pathological range. The RBMT is a very sensitive tool for agedependent memory problems and very appropriate to detect mild amnesia. This paper presents the first results with the Hungarian version of RBMT. The results of prospective and retrospective tasks compared and the data are discussed within a general theoretical framework.

Key words: $\quad$ amnesia, everyday forgetting, memory test, prospective memory 